NBER WORKING PAPER SERIES

STAR SCIENTISTS, INNOVATION AND REGIONAL AND NATIONAL IMMIGRATION

\author{
Lynne G. Zucker \\ Michael R. Darby \\ Working Paper 13547 \\ http://www.nber.org/papers/w13547 \\ NATIONAL BUREAU OF ECONOMIC RESEARCH \\ 1050 Massachusetts Avenue \\ Cambridge, MA 02138 \\ October 2007
}

This research has been supported by grants from the Ewing Marion Kauffman Foundation, the National Science Foundation (grants SES-0304727 and SES-0531146) and the University of California's Industry-University Cooperative Research Program (grants PP9902, P00-04, P01-02 and P03-01). An earlier version of this paper was presented at the 2nd annual Kauffman Foundation/Max Planck Institute Research Conference on Entrepreneurship, Dana Point, California, July 19-21, 2007. We are indebted to our research team members Emre Uyar, Jason Fong, Robert Liu, Tim Loon, Hongyan Ma and Amarita Natt. Certain data included herein are derived from the Science Citation Index Expanded, Social Sciences Citation Index, Arts \& Humanities Citation Index, High Impact Papers and ISI Highly Cited of the Institute for Scientific Information ${ }^{\circledR}$, Inc. (ISI $\left.{ }^{\circledR}\right)$, Philadelphia, Pennsylvania, USA: $\odot$ Copyright Institute for Scientific Information ${ }^{\circledR}$, Inc. 2005, 2006. All rights reserved. Certain data included herein are derived from the Zucker-Darby Science \& Technology Agents of Revolution (STAR) database @ Lynne G. Zucker and Michael R. Darby. All rights reserved. This paper is a part of the NBER's research program in Productivity. Any opinions expressed are those of the authors and not those of their employers or the National Bureau of Economic Research.

(C) 2007 by Lynne G. Zucker and Michael R. Darby. All rights reserved. Short sections of text, not to exceed two paragraphs, may be quoted without explicit permission provided that full credit, including (C) notice, is given to the source. 
Star Scientists, Innovation and Regional and National Immigration

Lynne G. Zucker and Michael R. Darby

NBER Working Paper No. 13547

October 2007, Revised February 2008

JEL No. J61,L26,O14,O31

\begin{abstract}
$\underline{\text { ABSTRACT }}$
We follow the careers 1981-2004 of 5401 star scientists listed in ISI HighlyCitedSM as most highly cited by their peers. Their number in a US region or a top- 25 science and technology (S\&T) country significantly increases the probability of firm entry in the S\&T field in which they are working. Stars rather than their disembodied discoveries are key for high-tech entry. Stars become more concentrated over time, moving disproportionately from areas with few peers in their discipline to many, except for a countercurrent of some foreign-born American stars returning home. High impact articles and university articles all tend to diffuse. America has 62 percent of the world's stars as residents, primarily because of its research universities which produce them. Migration plays a significant role in some developing countries.
\end{abstract}

Lynne G. Zucker

Departments of Sociology \& Public Policy

University of California, Los Angeles

Box 951551

Los Angeles, CA 90095-1551

and NBER

zucker@ucla.edu

Michael R. Darby

John E. Anderson Graduate School of Management

University of California, Los Angeles

110 Westwood Plaza, Box 951481

Los Angeles, CA 90095-1481

and NBER

michael.r.darby@anderson.ucla.edu 


\title{
Star Scientists, Innovation and Regional and National Immigration
}

\author{
Lynne G. Zucker and Michael R. Darby
}

The world, in fact, is only beginning to see that the wealth of a nation consists more than anything else in the number of superior men that it harbors .... Geniuses are ferments; and when they come together, as they have done in certain lands at certain times, the whole population seems to share in the higher energy which they awaken. The effects are incalculable and often not easy to trace in detail, but they are pervasive and momentous.

$$
\text { - William James (1911, p. 363) }
$$

In the last half of the twentieth century, America was the location of choice for the best and brightest scientific minds in the world. Recently America has partially rolled up its welcome mat to foreign doctoral and postdoctoral students while a reverse brain drain has set in for senior professors. Does this matter for the US economy or is it a matter of purely academic concern in both senses? This paper reports evidence that a sizable fraction of the very top scientists are responsible for startup firms across the broad range of high-technology industries whether they are in the United States or abroad. When America loses its star scientists - or star scientists in the making - it is losing not only their academic research and teaching, but new firms and jobs.

On the order of one third of the star scientists actually become involved in commercializing their discoveries at least once in their career; so losing a few hundred star scientists will have a small effect on the number of firms started in the US over the next generation. However, the firms started with star scientists as principals have proven to be the leading firms in terms of innovation and employment growth in a number of high-technology industries, such as biotechnology, lasers and semiconductors. In America and similar economies, most economic growth is concentrated at any given time in a relatively few firms in a relatively few industries experiencing very large productivity gains or introducing new products of much greater value than their cost of production (Harberger 1998, Darby and Zucker 2003). 
These firms are most often but not always somewhere en route from entrepreneurial start-up to large, industry-dominant firms. ${ }^{1}$ Losing to other countries star scientists who are likely to become star innovators is a recipe for shifting leading firms in specific new technologies abroad, leaving an imitative or no role for American firms.

This paper is organized in four sections. The first section discusses research findings in the literature on university-industry technology transfer before focusing on our research on the role of star scientists in determining where and when firms enter the biotechnology industry, which firms are most successful, how quickly they go public, and the stock market returns for particular firms. Section II presents evidence that - at least so far as starting firms is concerned these top scientists are star innovators across the gamut of high-tech industries. Section III presents evidence on the emergence of a reverse brain drain from the US to other countries that has reduced the number of these top scientists operating in and starting firms in the US. The final section offers conclusions and concerns for policymakers.

\section{Top Scientists as Star Innovators}

The importance of basic university science to successful commercialization of scientific discoveries has been confirmed in a number of other research studies, especially the importance of intellectual human capital (Di Gregorio and Shane 2003). Faculty are a key resource in creating and transferring early, discovery research via commercial entrepreneurial behavior (Yarkin 2000).

Jensen and Thursby (2001) confirm that active, self-interested participation of discovering professors is an essential condition for successful commercial licensing of most university inventions. Thursby and Thursby (2002) find that the sharp increase in university-industry technology transfer has not resulted so much from a shift in the nature of faculty research as from an 
increased willingness of faculty and administrators to license and increased interest on the part of firms.

Labor mobility of discovering scientists becomes very important in technology transfer, however, when a new discovery has both high commercial value and a combination of scarcity and tacitness that defines natural excludability, the degree to which there is a barrier to the flow of the valuable knowledge from the discoverers to other scientists (Zucker and Darby 1996b; Zucker, Darby and Brewer 1998). Those with the most information about breakthrough discoveries are the scientists actually making them, so there is initial scarcity.

To the extent that the knowledge is both scarce and tacit, as it often is in breakthrough discoveries, it constitutes intellectual human capital retained by the discovering scientists and is embodied in them. At the extreme, labor mobility is required to transfer the knowledge successfully (as found empirically by Jensen and Thursby 2001). To measure the extent of labor mobility of the stars, we use the count of 'linked' articles authored by stars with firm employees. These linked stars are most often local academic scientists-entrepreneurs who possess a significant equity or founding interest in the firm. The number of such articles serves as an indicator of the depth of the star's involvement with the firm's research effort. Nearly 70 percent of the ISI highly cited stars, who are the focus of Sections II and III, write at least one article with at least one firm employee, with 10 percent of all articles written by these stars linked to a firm.

In order to gain access to the knowledge of discovering scientists, firms in related areas of technology employ them. In most cases, the discovering scientists are initially employed by universities and research institutes; we are concerned with the extent to which they move at least part of their labor effort to specific firms. Some of these firms are incumbent firms which adopt 
the new technology (see Zucker and Darby 1996a, 1996b, 1997a, 1997b, Darby and Zucker 2001), but many of the firms are newly created around these star scientists, who often become residual owners as well as employees (Zucker, Darby and Brewer 1998). The discovering scientists often become the main resource around which firms are built or transformed (Zucker, Darby and Brewer 1998, Zucker, Darby and Armstrong 1998 and 2002; Darby and Zucker 2007; Zucker and Darby 2006). Star scientists are important in the process of technology transfer because the knowledge is both scarce and tacit and because their knowledge contributes significantly to the success of firms (Zucker, Darby and Torero 2002).

Our biotechnology database and research program was built around the 327 most productive scientists in terms of genetic sequence discoveries through 1989, a period encompassing the formative years of biotechnology but ending before the advent of automated sequencers which made our selection criterion obsolete in the 1990s. These 'star' scientists are truly among the best and brightest in the world: Accounting for only 0.7 percent of the authors of articles reporting genetic sequence discoveries through 1989, they accounted for 17.3 percent of the published articles. Great scientists - including these stars - differ from ordinary scientists in many ways, from mentoring fewer and brighter students to many more articles published, citations to those articles and patents (Zuckerman 1967, 1977; Zucker, Darby and Armstrong 1998). Not only did these scientists play a major role in shaping the advance of the science underlying biotechnology, our research has also shown that they played an important role in determining where and when firms entered biotechnology and which of those firms were most successful.

Zucker, Darby and Brewer (1998) and Darby and Zucker (2001) examined entry of new firms and incumbent firms into biotechnology in America and Japan, respectively. We argue there that the geographic distribution of a new science-based industry can be mostly derived from the 
geographic distribution of the intellectual human capital embodying the breakthrough discovery upon which it is based. This occurs when the discovery - especially an 'invention of a method of discovery' (Griliches 1957) - is sufficiently costly to transfer due to its uncodified complexity or tacitness (Nelson 1959; Arrow 1962, 1974; Nelson and Winter 1982; Rosenberg 1982) that the information can effectively be used only by employing those scientists in whom it is embodied. Technological opportunity and appropriability - the principal factors that drive technical progress for industries (Nelson and Wolff 1997; Klevorick, Levin, Nelson and Winter 1995) - are also the two necessary elements that created extraordinary value for our stars' intellectual human capital during the formative period of biotechnology. The employment of stars with a firm was often as a founding principal and usually part-time near their university laboratory (Zucker, Darby and Armstrong 1998; Zucker, Darby and Torero 2002). When the new techniques have diffused widely, access to stars is less essential, but once the technology has been commercialized in specific locales, internal dynamics of agglomeration tend to keep it there (Grossman and Helpman 1991; Marshall 1920; Audretsch and Feldman 1993, 1996; Head, Ries and Swenson 1995). ${ }^{2}$

In both the US and Japan, where and when star scientists are active has a strongly positive and significant independent effect on where and when biotech-using firms entered into biotechnology, and this effect is always separate from, and in addition to, the effects of research support for university scientists and local general economic conditions. We do find that intellectual capital variables play a relatively more important role for entry in the US whereas it is the local economic geography variables which are more significant in Japan.

As far as we know, neither we nor any other scholars have done any comparable research for Europe for this formative period through 1990. To a large degree, this may reflect a real disconnection during this period between academic science and industry. We recall a German 
pharmaceutical executive complaining, as late as the early 1990's, that the only way his firm could get German scientists to do genetic engineering for them was to employ them in the United States. A series of papers by Cooke (2001, 2004 and 2005) suggests that disconnection has since been bridged in some European metropolitan regions.

Table 1, adapted from Zucker and Darby (1999b), shows that Europe in fact had enough of the world's star scientists during the formative period to have been a major player in the commercial biotechnology revolution rather than playing the peripheral role that it did. Europe, including Russia and Israel, accounted for 32 percent of the stars, counted once per nation in which they published, compared to 62 percent for the US and Japan. The European university-industry disconnection is underlined by the fact that the corresponding percentages for stars ever working as or with a firm employee are 9 and 90 . Small net immigration into a few countries did not offset the large emigration from Britain and Switzerland to the benefit of the US and Japan. Anecdotal evidence suggests that the greater hospitality of the latter countries to academic scientistentrepreneurs played a role in this pattern with immigrants establishing firm ties soon after moving. We hypothesize in Section III on the reasons that the virtuous circles present in America and Japan may have been largely short-circuited in Europe.

We have found that the publication of articles by a star as, or with, a firm employee is a robust indicator of substantial involvement of that star with the firm. Substantial involvement of one or more star bioscientists was not a sufficient condition to make a firm successful, but it dramatically improved the odds relative to those firms that did not have it. For example, we consider the 38 publicly traded 1975 members of the Pharmaceutical Manufacturers Association. Of the 15 firms which developed working arrangements with star scientists by 1990, 80 percent (12 firms) survived until 1999. Of the 23 firms without such star participation, only 17.4 percent (4 
firms) survived to 1999 (Darby and Zucker 2001). A pharmaceutical firm not doing cutting edge biotechnology by the 1990s was either going out of business or into generics or other businesses.

In Zucker, Darby and Armstrong (1998) we analyzed the success of a census of Californian biotech firms in terms of number of products in development, number of products on the market and employment growth. We demonstrated that what appear to be 'geographically localized knowledge spillovers' (positive externalities as proposed by Jaffe 1986; Jaffe, Trajtenberg and Henderson 1993) from academic science to research productivity of nearby firms were in fact concentrated in the relatively few firms with stars linked via co-authorship whereas other firms gained no advantage from locating near the leading research universities. ${ }^{3}$ These results were obtained from poisson regressions which controlled for the effect of firm characteristics such as incumbency-new-entrant status, technology used and time since entry. The estimated effects are quite significant as indicated in the left side of Figure 1. The more star-linked articles a firm had - indicating deeper involvement of the star at the bench level - the better the firm did, whether judged by products in development, products on the market or employment. These differences are large enough to explain the difference between success and failure: A biotech firm with no star-linked articles (with all other factors set to their mean values) had an expected employment growth of 80 workers from 1984 to 1989 compared to 341 and 734 for firms with 2 and 5 articles, respectively.

We replicated these results for Japan in Zucker and Darby (2001), with the star impacts indicated on the right half of Figure 1. There are two notable differences from the California results: Firstly, the entire profile of products on the market in Japan is much lower and flatter, as they were lagging behind California by approximately 5 years. Secondly, we were unable to get usable estimates of biotechnology employment for Japanese firms which were almost exclusively large incumbent firms using the technologies in a limited sector of their businesses. As a result we 
substituted the number of US patents granted as a third measure of success and found results that fit the pattern of strong effects from star involvement.

There is much more evidence that the star scientists play a special role, independently from their potentially separable research discoveries, in shaping the formation and transformation of biotechnology-using industries. Figure 2 (adapted from Zucker, Darby and Armstrong 2002, Figure 2) illustrates that star articles are a much stronger indicator of firm success than popular alternatives such as all firm articles co-authored with top-research-university faculty members or venture capital funding. Audretsch and Stephan (1996) had analyzed the locational patterns of university scientists appearing in the prospectuses of biotechnology firms going public March 1990 and November 1992, many of whom overlapped with our set of stars. In Darby and Zucker (2007) we show that firms with deeper star involvement do go public significantly more quickly than other biotech firms; implying that the characteristics described by Audretsch and Stephan differed systematically from the entire population of private biotech firms at risk for going public. Darby, Liu and Zucker (2004) show that not only does the stock market value star involvement in pricing publicly traded biotech firms, but those firms follow different high risk, high return strategies reflected in larger jumps or discontinuities in the evolution of their stock prices. Zucker and Darby (2007a) show that the stars' contributions to open science increase during their period of involvement with a firm, so that both science and commerce profit in the mutually reinforcing 'virtuous circle' alluded to previously. ${ }^{4}$

In short, direct involvement of the very best academic scientists in commercialization of cutting-edge discoveries is a key determinant of which firms will win the competitive race and which will fall by the wayside. In high-technology, the race most often goes to the smartest. 


\section{Top Scientists and Entry of High-Technology Firms}

We are beginning to investigate whether or not top scientists provide important top innovators across the gamut of high-technology industries, or whether this is a characteristic only of scientific areas undergoing very rapid change, like biotechnology and nanotechnology. We report here on the results for whether or not the presence of top scientists in a region or country generally lead to more entry there of firms in related technologies. Complete details of the statistical procedures, data, and results can be found in Zucker and Darby (2006).

\section{II.A. Data}

This project is challenging because data are difficult and costly to obtain and far from perfect for investigating entrepreneurial companies, particularly in the formative years of a new technology when most of the firms are not publicly traded and hence not required to make public disclosures. The entry of high-technology firms into a technology can be approximately dated from the date of their first patent application or scientific-article publication. For NanoBank.org, we developed as complete as possible a list of companies using nanotechnology (Zucker and Darby 2007b; Zucker, Darby, Furner, Liu and Ma 2007). We verified that substituting entry dates for those firms gave us essentially the same results as we obtained using the patentingpublication method of identifying firms.

We examine the pattern of firm entry for six science and technology areas (Biology, Chemistry \& Medicine; Computing \& Information Technology; Semiconductors, Integrated Circuits \& Superconductors; Nanoscale Science \& Technology; Other Sciences; and Other Engineering). The five areas other than nanotechnology were developed for and detailed in analyses reported in Darby and Zucker (1999) and Zucker and Darby (1999a) that span scientific articles, patents, and university doctoral-programs data from the National Research Council 
(1995). We were unable to find finer breakdowns that did not require data in greater detail in one or more of these sources. Under National Science Foundation funding, we are developing a public digital database Nanobank.org which permits us to extract specific articles and patents for nanotechnology from the other five areas in which they would otherwise appear. See Zucker, Darby, Furner. Liu and Ma (2007) for a discussion of the methodology used to define nanotechnology articles and patents. Geographic units are alternatively the 179 US functional economic regions or the 25 top science and technology countries in the world in terms of patenting and publication. ${ }^{5}$

Another data challenge has been identifying star scientists across the broad range of scientific and engineering disciplines. In our previous research, we have identified the stars using measures of scientific productivity uniquely tailored to the particular science area and independent of their direct involvement in the commercialization of their discoveries. In order to generalize the star concept, we needed to find a criterion of scientific productivity which was comparable across fields and not dependent on whether or not the star was actually involved in commercialization. (Since we are investigating star scientists who do commercialize their inventions, we need to define top scientists independent of that involvement.)

The Institute for Scientific Information ${ }^{\circledR}$, Inc. $\left(\right.$ ISI $^{\circledR}$ ) has developed the ISI Highly Cited component of the ISI Web of Science ${ }^{\circledR}$ which is very close to what is needed. The ISI HighlyCited.com website (Institute for Scientific Information 2005b) offers a database of the top 250 individual researchers in terms of 20-year-rolling-window citation counts in each of 21 subject fields -19 of which are science and engineering fields. Information for each highly cited author includes a curriculum vitae (usually full but sometimes abbreviated ${ }^{6}$ ), a list of publications taken from the author's curriculum vitae, and links for those publications in ISI- 
listed journals to the full bibliographic information indexed in the ISI Web of Science ${ }^{\circledR}$ (Institute for Scientific Information 1981-1997, 2005a). Altogether we thus identify 5,401 star scientists, one or more of who are credited with authorship of some 520,839 articles that appear in the ISI Web of Science ${ }^{\circledast}$ database. The articles are used to identify where the stars are active based on those 299,583 cases (52.5 percent of the appearances of stars as authors) where their affiliation is unambiguous. ${ }^{7}$ We have used these addresses to identify each US region or non-US country in which these star scientists were active 1981-2004. We code the stars as active in a region from two years before their first publication there until they move to another location. During transitional phases they are coded as active for up to two years in both locations. Stars who maintain long-term affiliations in multiple countries also are coded as active in each location.

\section{II.B. Empirical Results}

Figures 3 and 4, taken from Zucker and Darby (2006), illustrate the relationship between stars ever active and cumulative firm entry 1981-2004 for US regions for the largest science and technology area (biology-chemistry-medicine) and the newest (nanoscale science \& technology), respectively. In each case there is a high correlation between the number of star scientists and the number of firms that have entered the corresponding area of science and technology. However, the actual number of stars is much smaller relative to the number of new firms in the nanoscale S\&T area than in the biology-chemistry-medicine area. We believe that this difference reflects the speed with which discoveries with nanotechnology application are being commercialized versus the slowness of recognition of star scientists in this new multidisciplinary area based on counts of citations to their work relative to other publications in the same preexisting discipline as the journals in which most of an author's articles appear. 
Figures 5 and 6, also taken from Zucker and Darby (2006), illustrate the relationship between stars ever active and cumulative firm entry 1981-2004 for the top-25 science and technology countries in the world for the same two science and technology areas as Figures 3 and 4. The pattern is strikingly similar to what was seen for US regions. It would take literally hundreds of maps to cover all six science and technology areas for entry and star presence each year at the US regional level and nationally. Furthermore, maps cannot adequately account for other variables which may account for the correlation. In Zucker and Darby (2006) we have used advanced statistical methods to simultaneously take account of other measures of scientific base and economic geography. We were particularly concerned with including measures of the actual discoveries in a region (patents, highly-cited articles, other articles) to distinguish the effect of the stars personally from that of their discoveries.

The statistical results are clear: Holding other measures of scientific base and economic geography constant, regions or countries with more of these top scientists present in one of the six S\&T areas also exhibit a significantly higher rate of firm entry in that S\&T area. The effects are quite large in magnitude as illustrated in Figure 7, adapted from Zucker and Darby (2006). The left half of the figure refers to estimates based on data for US regions for each year, 19812004. The right half of the figure refers to estimates based on the 24 non-US countries among the top 25 S\&T countries in the world. Separate estimates on the effects of star scientists on the rate of firm entry by region per year and by country per year are obtained for each of the 6 S\&T areas which are abbreviated at the bottom of the horizontal axis. The height of the bar indicates the predicted rate of entry for a particular assumed number of stars in the region or country given that all the other determinants are at their mean values relative to the same rate if the number of stars was also equal to its mean value. The first bar in the quartet for a given S\&T area gives the 
relative probability assuming there is one star scientist in the S\&T area \& region/country a given year. The second bar - always equal to 1 - is the relative ratio if the assumed number of stars equals the mean value. The third and fourth bars increase the number of stars above the mean by one and by two standard deviations, respectively. The associated increase in the rate of firm entry is substantial - in several cases astonishing so - for all cases except for the anomalous negative effect for Other Sciences in the top-24 non-US S\&T countries. That anomalous case, semiconductors for both samples and computing/IT for the US case are not statistically significantly different from zero, but all the other estimates are significantly positive. If we consider the estimates - not illustrated in Figure 7 - for all top-25 S\&T countries (including the US) then entry has a significant positive impact in every case. However, since the data may impart a US-centric bias and since the much higher number of stars in the US than in any of the other countries may pick up any institutional advantages for entrepreneurial entry, we will not consider those estimates further.

We have conducted various experiments to test the robustness of the results. One set of questions concerns our use of the date of the first patent application or scientific-article publication in a region/country and S\&T area to measure the entry date of high-technology firms in that place and technology area. We do it because there is generally no alternative. However, for NanoBank.org, we developed as complete as possible a list of companies using nanotechnology using industry directories, web searches and other archival sources (Zucker and Darby 2007b). We verified that substituting entry dates for those firms gave us essentially the same results as we obtained using the patenting-publication method of identifying firms.

Another concern was that the ISI Highly Cited numbers were large relative to previously used techniques for identifying star scientists in particular technology areas. We restricted our 
list of stars to the first third reported in ISI - roughly the top 100 in each of the 19 science and engineering fields - and obtained slightly improved results illustrated in Figure 8, drawn from results reported in Tables A.2 and A.4 in Zucker and Darby (2006). The headline results are very similar to those in Figure 7, but this is surprising unless the impact of the remaining stars is higher than those whose information we have discarded from the statistical analysis.

These results are only a first step in demonstrating that the very best and brightest scientists frequently become involved in commercializing their discoveries, often as a founder or cofounder of an entrepreneurial firm. We believe that it is a large first step in the direction of showing that these extraordinary individuals play a role in innovation and growth across the full spectrum of high technology industries.

\section{Emergence and Migration of Top Scientists}

Given the right institutional conditions, a significant fraction of star scientists become star innovators who drive growth and progress via creating and transforming high-technology industries, usually while continuing to make major contributions to science. These individuals are true geniuses in the original sense - not just having extraordinary intelligence and transcendent creativity but actively using it to transform their world and ours. Finding time and resources to do all that they are doing is an ongoing struggle and they rarely become involved in starting new companies or transforming existing ones very far from where they are doing the rest of their work. Therefore, the geographies of technological progress and star scientists tend to coincide. In this section we will consider where the stars begin their professional careers, change regions or locations of residence and/or enter new scientific fields. 
Economic geography provides us with the useful concepts of agglomeration and diffusion, which are two sides of the same coin. Agglomeration occurs with respect to a particular measure of interest if concentration is increasing over time: regions or countries with larger values of this measure have disproportionately high growth rates for the same measure while those with lower values have disproportionately low growth rates. High-technology industries, for example, tend to concentrate over time or agglomerate in a relatively few centers, and knowledge in a specialty or subspecialty tends to grow faster in centers which have achieved a 'critical mass' of scholars (Zucker, Darby, Furner, Liu and Ma 2007). Diffusion is the mirror image of agglomeration: regions or countries with smaller values have disproportionately high growth rates for the measure being considered while those with higher values have disproportionately low growth rates. Diffusion is the goal of many economic development schemes, notably in the European Union, as well as a natural process for the spread of knowledge.

The correlation coefficient of the level and growth rate of a variable measured across regions or countries and over time is a direct index of agglomeration or diffusion. If the correlation coefficient (which ranges from -1 to 1 ) is positive, the variable is agglomerating while a negative correlation coefficient shows that the variable is diffusing over time. In Table 2, adapted from Table 5 in Zucker and Darby (2007c) and Table 8 in Zucker and Darby (2006), we present these correlation coefficients for a number of variables of interest and for different sets of countries. Whether we look at US regions or any of the listed combinations of the top-25 S\&T countries in the world, university article publication is diffusing, with traditionally weaker regions and countries tending to catch up with traditional scientific leaders. This suggests that more regions and countries will over time provide a fertile ground for new star scientists to 
emerge where before it would be very difficult. This observation is confirmed - but more weakly - by the tendency for high impact articles (those that are very highly cited by other scientists) to diffuse, although that diffusion is statistically significant only where the US is not included in the set of countries.

The third line for each geographical comparison tells us that firm entry is in fact agglomerating across the gamut of broad high-technologies both across US regions and across the non-OECD [developing] countries among the top-25 S\&T countries. On the other hand, this tendency toward concentration of broad high-technologies is not statistically significant or nonexistent for the geographic comparisons including 18 (without US) or 19 (with US) of the OECD [developed] countries. Whether or not high-technology firm entry is agglomerating seems to be determined in substantial part by whether or not star scientists are agglomerating, with that tendency is strongest across US regions and across the non-OECD countries among the top-25 S\&T countries. Star scientists entry shows strong agglomeration and tends to drive agglomeration of the number of star scientists resident in a region or country unless offset by migration (Zucker and Darby 2007c).

Overlaying this pattern during the last quarter century, however, are movements of many US trained foreign students who build successful careers in American academe, perhaps moving from lower to higher ranked US universities but choose to return home when their native countries develop sufficient strength in their disciplines to both seek them out and to be attractive (Saxenian 2005). This weakens the tendency toward concentration when the US is in the country data set, but not when it is out. Since this effect is present to a somewhat similar degree in all American universities, the reverse brain drain of expatriate stars affects the average growth rate of stars in the US without weakening the positive correlation across countries. 
Table 3, from Table 6 in Zucker and Darby (2007c), presents novel evidence on the location and migration of star scientists and engineers among the top-25 S\&T countries. About 93 percent of the world's star scientists and engineers in the world have residences in the top-25 S\&T countries at the end of $2004-62$ percent in the US alone. ${ }^{8}$ It should be noted that non-US scientists suspect that ISI citation measures and therefore the ISI Highly Cited are inherently biased in favor of English-speaking and particularly American scientists (and, in fact, there must be published English translations of titles and abstracts for a non-English language to be ISIlisted). The dominant factor determining the number of stars resident in a country at the end of the period or at any time during the period is the number of professional debuts made in the country. Future stars are more likely to get their first job where they want to live and they tend to stay there. However, migration does make a difference for some countries and losing even one or two dominant firms founded by emigrants to other countries can be a significant economic event.

Table 3 shows clear evidence of reversal of the traditional brain drain from other countries, particularly less developed ones, to the US and other science powerhouses like Britain and Germany. The four largest net immigrations of star scientists over the last quarter century were registered by the United Kingdom (-27 or 4.6 percent of all stars resident in the country at any time $1981-2004)$, the United States (-23 or 0.6 percent), Canada (-23 or 7.7 percent) and Germany (-11 or 3.0 percent). Recall that Table 1 showed that for biotechnology stars (defined by genetic-sequence discoveries, not citations) 1973-1989, the US and Germany had inward net migration of 2.9 and 8.3 percent, respectively; so for these countries there is evidence of a reversal of direction. ${ }^{9}$ 
For the six developing countries near the bottom of Table 3, round-trip inward migration (where a star moves there for more than two years but later leaves) provides a significant source of brain power and innovation accounting for from 33 to 79 percent of all star scientists ever resident in those countries, 1981-2004. Moreover, about 20 percent of all inward migrant stars to these countries had not returned as of 2004, mostly due to those remaining in China and Taiwan.

At this point we read the evidence on migration of stars as cautionary for the US, but alarming for some other countries (such as Canada, Germany, Israel and the United Kingdom). We also see hope for some developing countries that inward migration (frequently of native born, foreign-educated stars) can provide an important supplement to home-grown stars if working and living conditions are right to attract and retain them (Zucker and Darby 2007c).

\section{Conclusions}

From the bare economic point of view the importance of geniuses is only beginning to be appreciated. How can we measure the cash-value to France of a Pasteur, to England of a Kelvin, to Germany of an Ostwald, to us here of a Burbank? One main care of every country in the future ought to be to find out who its first rate thinkers are and to help them. Cost here becomes, irrelevant, the returns are sure to be so incommensurable.

$$
\text { - William James (1911, pp. 363-364) }
$$

William James - the father of American psychology and a first rate thinker - apparently foresaw the extraordinarily high estimates of the return current in the economics of S\&T literature and perhaps the coming of the National Science Foundation, the National Institutes of Health and their sister institutions in the US and other countries. However, democratic values largely trumped the study - much less appreciation or even mention - of geniuses as a politically incorrect vestige of the 'great man theory' which should be consigned to the dustbin of history. 
It is only the accumulation of stubborn facts that has persuaded us that this view is fundamentally wrong so far as it comes to understanding innovation.

Innovation is mostly not about the accumulation of small changes - inching up as the Japanese would have it - but about the rare occurrence of very large improvements in how to do things or what can be done. Inching up may be better done by 100 journeyman engineers than 1 or 2 scientific geniuses but great innovations are much more likely to come from the geniuses.

The star scientists in this paper are remarkably energetic, and when they see that one of their discoveries has substantial commercial value and the incentives (including funding more research) are right, they find a way to sell their idea to an existing firm or create a new one to commercialize it. They are opportunists in the best senses of the word: creating opportunity, seeing it where others do not and carrying forward with a drive that gets things accomplished despite an already overfull agenda. James calls on the government to help them, but often it is enough to simply stay out of their way. They are quite used to helping themselves and smart enough to speak of team work, generally relying on small teams of extraordinary scientists or scientists-in-training (Zuckerman 1977).

The American system of research universities has been remarkably effective in providing a flexible home base for star innovators to work from. For decades America attracted the best and brightest from around the world to come for a doctoral education. The very best of these often never left, contributing to US growth. A century and a half ago Germany benefited from its similar role as the center of science. James included among his four exemplars of genius with obviously great cash value Wilhelm Ostwald (1853-1932), the 1909 Nobel Laureate for Chemistry for his work on catalytic reactions and Professor of Physical Chemistry at Leipzig University in Germany 1887-1906. In the commercial realm, the Ostwald process for producing 
nitric acid remains a mainstay of the modern chemical industry. We should note that Ostwald, a native of Riga, Latvia, was also an exemplar of the value of brain drain to the receiving country.

Our earlier research has shown the importance of star scientists in their commercial role of star innovators creating the dominant firms in important industries driven by rapid scientific progress. Our results on firm entry suggest that this is true across the broad range of hightechnology industries. The individuals at the very top of their scientific discipline are the ones most likely to fundamentally change how things are done in their science and in its commercial applications. America has profited greatly from providing a seed bed for producing and retaining most of these people for the last sixty years. There is evidence that recent policy changes such as on student visas have endangered that privileged status. It would be a very costly loss. 


\section{Endnotes}

1 Baumol, Litan and Schramm (2007) argue persuasively that both small entrepreneurial firms and large dominant firms play important roles in growth and prosperity. Darby and Zucker (2006) argue that the prospect of a small entrepreneurial firm's becoming a large dominant firm provides part of the incentive to bear the costs of turning a great idea into a commercial innovation in a startup firm.

2 This market-based model is an alternative - and empirically superior as discussed below explanation for clustering of high-tech industries around universities to positive externalities (such as quicker knowledge diffusion through attending seminars) as advocated Jaffe (1986), Dorfman (1988), Jaffe, Trajtenberg and Henderson (1993), Bania and Fogarty (1993), and Saxenian (1996). It also differs from the Crane $(1969,1972)$ invisible colleges view in which geography and benchscience interaction have vanishing importance.

${ }^{3}$ These knowledge spillovers play a central role in the economics literature as causes of geographic agglomeration (local concentration) of particular industries and of endogenous growth in the 'New Growth Theory Models’ (Romer 1986, 1990; Grossman and Helpman 1991; Eaton and Kortum 1996, 1999; Jones 1995) though the empirical search for their existence has proved difficult (Griliches 1992). Demonstration of statistically significant positive effects on a firm's productivity of being near great universities and other sources of scientific discovery also have been taken as fingerprints of such spillovers by Acs and Audretsch 1988 and 1993, Acs, Audretsch, and Feldman 1994, and Mansfield 1995.

4 The stars' contributions to open science are measured in Zucker and Darby (2007a) by the number of articles published per year, given that the citations per article increase in the US and are insignificantly different in Japan.

${ }^{5}$ The US Bureau of Economic Analysis defines the 179 regions as functional economic areas such 
that each US county is assigned to a region which includes the major metropolitan center for which commuting, shopping, and newspaper readership predominates (Johnson and Kort 2004). The 25 countries are: Australia, Austria, Belgium, Brazil, Canada, China, Denmark, Finland, France, Israel, India, Italy, Japan, Germany, the Netherlands, Norway, Poland, South Korea, Spain, Sweden, Switzerland, Taiwan, the United Kingdom, the United States, and the USSR \& Russia counted as the same country.

6 The curriculum vitae supplied to ISI author appears to be in an abbreviated (apparently NSF or $\mathrm{NIH}$ ) format for 41.0 percent of these stars, with $37.8 \%$ reporting exactly 10 ISI articles and 3.2 percent reporting 5-9 ISI articles. Since the NSF and NIH formats impose strict 10-publications and 1-3 pages limits (the latter depending on the grant program), listed publications and affiliations are chosen strategically to enhance the odds of funding. Less prestigious, especially commercial, affiliations are also not infrequently omitted from full academic curricula vitae so we chose to identify location by those listed at the time of publication of articles rather than rely on the ones reported retrospectively.

7 ISI article data do not distinguish which address (normally an organization) goes with which author except for a possible single author designated corresponding author who then matches (at least) to the corresponding address). The cases indicated in the text are those for which the star scientist can be definitively located with an address because they are the corresponding author, the sole author, or there is only 1 listed corresponding or research address for a journal that reports multiple addresses on other articles in the same year. The 299,583 authorships corresponded to 276,182 different articles, with the difference $(23,401)$ all accounted for by multiple star authors on articles with a single address.

${ }^{8}$ A small number of the stars have residences in two countries, judging from their publications 
and patents, and a handful made their professional debut simultaneously in two countries, presumably reflecting the locations of their doctoral work and first job.

${ }^{9}$ On the other hand, the United Kingdom and Canada had large outward migration rates in Table 1 (32.3 and 30.0 percent, respectively) so those countries were already experiencing a brain drain. Switzerland reversed its direction in a favorable direction for that country between the two tables. 


\section{$\underline{\text { References }}$}

Acs, Zoltan J. and David B. Audretsch (1987), 'Innovation, Market Structure, and Firm Size', Review of Economics and Statistics, 69 (4), 567-574.

Acs, Zoltan J. and David B. Audretsch (1993), 'Innovation and Technological Change: The New Learning', Advances in the Study of Entrepreneurship, Innovation, and Economic Growth, 6 , 109-142.

Acs, Zoltan, David B. Audretsch and Maryann P. Feldman (1994), 'R\&D Spillovers and Innovative Activity’, Managerial and Decision Economics, 15, 131-138.

Arrow, Kenneth J. (1962), 'Economic Welfare and the Allocation of Resources for Invention', in Richard R. Nelson (ed), The Rate and Direction of Inventive Activity: Economic and Social Factors, NBER Special Conference Series vol. 13, Princeton, US: Princeton University Press, pp. 609-625.

Arrow, Kenneth J. (1974), The Limits of Organization, New York, US: W.W. Norton \& Company.

Audretsch, David B. and Maryann P. Feldman (1994), 'The Geography of Innovation and Production', in Consorcio de la Zona Franca di Vigo (ed), The Location of Economic Activity: New Theories and Evidence, London: Centre for Economic Policy Research.

Audretsch, David B. and Maryann P. Feldman (1996), 'R\&D Spillovers and the Geography of Innovation and Production', American Economic Review, 86 (3), 630-640.

Audretsch, David B. and Paula E. Stephan (1996), 'Company-Scientist Locational Links: The Case of Biotechnology’, American Economic Review, 86 (3), 641-652.

Bania, Neil, Randall Eberts and Michael Fogarty (1993), 'Universities and the Startup of New Companies: Can We Generalize from Route 128 and Silicon Valley?', Review of Economics and Statistics, 75, 761-766.

Baumol, William J., Robert E. Litan and Carl J. Schramm (2007), Good Capitalism, Bad Capitalism, and the Economics of Growth and Prosperity, New Haven, US and London, UK: Yale University Press.

Cooke, Philip (2001), 'Regional Innovation Systems, Clusters, and the Knowledge Economy', Industrial and Corporate Change, 10 (4), 945-974.

Cooke, Philip (2004), Globalisation of Bioregions: The Rise of Knowledge Capability, Receptivity \& Diversity, Regional Industrial Research Report 44, Cardiff, UK: Centre for Advanced Studies.

Cooke, Philip (2005), 'Rational Drug Design, the Knowledge Value Chain and Bioscience Megacentres', Cambridge Journal of Economics, 29 (3), 325-341.

Crane, Diana (1969), 'Social Structure in a Group of Scientists: A Test of the Invisible College Hypothesis', American Sociological Review, 34 (3), 335-52.

Crane, Diana (1972), Invisible Colleges: Diffusion of Knowledge in Scientific Communities, Chicago, US: University of Chicago Press.

Darby, Michael R., Qiao Liu and Lynne G. Zucker (2004), 'High Stakes in High Technology: High-tech Market Values as Options’, Economic Inquiry, 42 (3), 351-369. 
Darby, Michael R. and Lynne G. Zucker (1999), California's Science Base: Size, Quality and Productivity, Sacramento, US: California Council on Science and Technology.

Darby, Michael R. and Lynne G. Zucker (2001), 'Change or Die: The Adoption of Biotechnology in the Japanese and U.S. Pharmaceutical Industries', Comparative Studies of Technological Evolution, 7, 85-125.

Darby, Michael R. and Lynne G. Zucker (2003), 'Growing by Leaps and Inches: Creative Destruction, Real Cost Reduction, and Inching Up', Economic Inquiry, 41 (1), 119.

Dorfman, Nancy S. (1988), 'Route 128: The Development of a Regional High Technology Economy', in David Lampe (ed.), The Massachusetts Miracle: High Technology and Economic Revitalization, Cambridge, US: The MIT Press, pp. 240-274.

Michael R. Darby and Lynne G. Zucker (2006), 'Innovation, Competition, and WelfareEnhancing Monopoly', National Bureau of Economic Research Working Paper No. 12094.

Darby, Michael R. and Lynne G. Zucker (2007), 'Grilichesian Breakthroughs: Inventions of Methods of Inventing in Nanotechnology and Biotechnology', Annales d'Economie et Statistique, 79-08, in press.

Di Gregorio, Dante and Scott Shane (2003), 'Why do some universities generate more start-ups than others?', Research Policy, 32 (2), 209-227.

Eaton, Jonathan and Samuel Kortum (1996), 'Trade in Ideas: Patenting and Productivity in the OECD', Journal of International Economics, 40 (3-4), 251-78

Eaton, Jonathan and Samuel Kortum (1999), 'International Technology Diffusion: Theory and Measurement', International Economic Review, 40 (3), 537-570.

Griliches, Zvi (1957), 'Hybrid Corn: An Exploration in the Economics of Technological Change’, Econometrica, 25 (4), 501-522.

Griliches, Zvi (1992), 'The Search for R\&D Spillovers', Scandinavian Journal of Economics, 94 (Supplement), 29-47.

Grossman, Gene M. and Elhanan Helpman (1991), Innovation and Growth in the Global Economy, Cambridge, US: The MIT Press.

Harberger, Arnold C. (1998), 'A Vision of the Growth Process', American Economic Review, 88 (1), 1-32.

Head, Keith, John Ries and Deborah Swenson (1995), 'Agglomeration Benefits and Location Choice: Evidence from Japanese Manufacturing Investment in the United States', Journal of International Economics, 38 (3-4), 223-247.

Institute for Scientific Information (1981-1997), Science Citation Index, machinereadable data bases, Philadelphia, US: Institute for Scientific Information.

Institute for Scientific Information (2005a), Science Citation Index Expanded, Social Sciences Citation Index, Arts \& Humanities Citation Index and High Impact Papers, machine-readable data bases, Philadelphia, US: Institute for Scientific Information. 
Institute for Scientific Information (2005b), $\underline{\text { ISI HighlyCited }}{ }^{\mathrm{SM}}$, on-line machine-readable data base, Philadelphia, US: Institute for Scientific Information, http://isihighlycited.com/.

Jaffe, Adam B. (1986), 'Technological Opportunity and Spillovers of R \& D; Evidence from Firms’ Patents, Profits, and Market Value’, American Economic Review, 76 (5), 984-1001.

Jaffe, Adam B., Manuel Trajtenberg and Rebecca Henderson (1993), 'Geographic Localization of Knowledge Spillovers as Evidenced by Patent Citations', Quarterly Journal of Economics, 63, 577-598.

James, William (1911), 'Stanford's Ideal Destiny', Memories and Studies, New York, US: Longmans, Green \& Co., pp. 356-367.

Jensen, Richard and Marie Thursby (2001), 'Proofs and Prototypes for Sale: The Tale of University Licensing', American Economic Review, 91 (1), 240-259.

Johnson, Kenneth P. and John R. Kort (2004), '2004 Redefinition of the BEA Economic Areas', Survey of Current Business, November, pp. 68-75.

Jones, Charles I. (1995), 'R\&D-Based Models of Economic Growth', Journal of Political Economy, 103 (4), 759-784

Klevorick, Alvin K., Richard C. Levin, Richard R. Nelson and Sidney G. Winter (1995), 'On the Sources and Significance of Interindustry Differences in Technological Opportunities’, Research Policy, 24 (2), 185-205.

Mansfield, Edwin (1995), 'Academic Research Underlying Industrial Innovations: Sources, Characteristics, and Financing', Review of Economics and Statistics, 77 (1), 55-65.

Marshall, Alfred (1920), Principles of Economics, 8th ed., London, UK: Macmillan.

National Research Council (1995), Research-Doctorate Programs in the United States: Data Set, machine-readable data base, Washington, US: National Academy Press.

Nelson, Richard R. (1959), 'The Economics of Invention: A Survey of the Literature', Journal of Business, 32 (2), 101-127.

Nelson, Richard R. and Sidney G. Winter (1982), An Evolutionary Theory of Economic Change, Cambridge, US: Harvard University Press.

Nelson, Richard R. and Edward N. Wolff (1997), 'Factors behind Cross-Industry Differences in Technical Progress', 8 (2), 205-220.

Romer, Paul M. (1986), 'Increasing Returns and Long-Run Growth', Journal of Political Economy, 94 (5), 1002-1037.

Romer, Paul M. (1990), 'Endogenous Technological Change', Journal of Political Economy, 98 (5, Part 2-Supplement), S71-S102.

Rosenberg, Nathan (1982), Inside the Black Box: Technology and Economics, Cambridge, UK: Cambridge University Press.

Saxenian, AnnaLee (1996), Regional Advantage: Culture and Competition in Silicon Valley and Route 128, Cambridge, US: Harvard University Press.

Saxenian, AnnaLee (2005), 'From Brain Drain to Brain Circulation: Transnational Communities and Regional Upgrading in India and China', Studies in Comparative International Development, $\underline{40}$ (2), 35-61. 
Thursby, Jerry G. and Marie Thursby (2002), 'Who Is Selling the Ivory Tower? Sources of Growth in University Licensing', Management Science, 48 (1), 90-104.

Yarkin, Cherisa (2000), 'Assessing the role of the University of California in the state's biotechnology economy', in John de la Mothe and Jorge Niosi (eds), The Economic and Social Dynamics of Biotechnology, Boston, US: Kluwer Academic Publishers.

Zucker, Lynne G. and Michael R. Darby (1996a), 'Costly Information: Firm Transformation, Exit, or Persistent Failure’, American Behavioral Scientist, 39 (8), 959-974.

Zucker, Lynne G. and Michael R. Darby (1996b), 'Star Scientists and Institutional Transformation: Patterns of Invention and Innovation in the Formation of the Biotechnology Industry', Proceedings of the National Academy of Sciences, $\underline{93}$ (23), 12709-12716.

Zucker, Lynne G. and Michael R. Darby (1997a), 'Individual Action and the Demand for Institutions: Star Scientists and Institutional Transformation', American Behavioral Scientist, 40 (4), 502-513.

Zucker, Lynne G. and Michael R. Darby (1997b), 'Present at the Biotechnological Revolution: Transformation of Technical Identity for a Large Incumbent Pharmaceutical Firm', Research Policy, 26 (4\&5), 429-446.

Zucker, Lynne G. and Michael R. Darby (1999a), California's Inventive Activity: Patent Indicators of Quantity, Quality, and Organizational Origins, Sacramento, US: California Council on Science and Technology.

Zucker, Lynne G. and Michael R. Darby (1999b), 'Star Scientist Linkages to Firms in APEC and European Countries: Indicators of Regional Institutional Differences Affecting Competitive Advantage', International Journal of Biotechnology, 1 (1), 119-131.

Zucker, Lynne G. and Michael R. Darby (2001), 'Capturing Technological Opportunity Via Japan's Star Scientists: Evidence from Japanese Firms' Biotech Patents and Products', Journal of Technology Transfer, 26 (1/2), 37-58.

Zucker, Lynne G. and Michael R. Darby (2006), 'Movement of Star Scientists and Engineers and High-Tech Firm Entry', National Bureau of Economic Research Working Paper No. 12172, April, revised October.

Zucker, Lynne G. and Michael R. Darby (2007a), 'Virtuous Circles in Science and Commerce', Papers in Regional Science, 86 (3), 468-471.

Zucker, Lynne G. and Michael R. Darby (2007b), 'Socio-economic Impact of Nanoscale Science: Initial Results and NanoBank', in Mihail C. Roco and William S. Bainbridge (eds), Nanotechnology: Societal Implications II - Individual Perspectives, Dordrecht, The Netherlands: Springer.

Zucker, Lynne G. and Michael R. Darby (2007c), 'Science, Knowledge, and Firms in Developing Economies', paper presented at the Micro Evidence on Innovation in Developing Economies, MERIT, United Nations University, Maastricht, The Netherlands, May 31-June 1.

Zucker, Lynne G., Michael R. Darby and Jeff Armstrong (1998), 'Geographically Localized Knowledge: Spillovers or Markets?', Economic Inquiry, 36 (1), 65-86. 
Zucker, Lynne G., Michael R. Darby and Jeff Armstrong (2002), 'Commercializing Knowledge: University Science, Knowledge Capture, and Firm Performance in Biotechnology', Management Science, 48 (1), 138-153.

Zucker, Lynne G., Michael R. Darby and Marilynn B. Brewer (1998), 'Intellectual Human Capital and the Birth of U.S. Biotechnology Enterprises', American Economic Review, 88 (1), 290-306.

Zucker, Lynne G., Michael R. Darby, Jonathan Furner, Robert C. Liu and Hongyan Ma (2007), 'Minerva Unbound: Knowledge Stocks, Knowledge Flows and New Knowledge Production', Research Policy, 36 (6), 850-863.

Zucker, Lynne G., Michael R. Darby and Máximo Torero (2002), 'Labor Mobility from Academe to Commerce', Journal of Labor Economics, 20 (3), 629-660.

Zuckerman, Harriet (1967), 'Nobel Laureates in Science: Patterns of Productivity, Collaboration, and Authorship', American Sociological Review, 32 (3), 391-403

Zuckerman, Harriet (1977), Scientific Elite: Nobel Laureates in the United States, New York, US: Free Press. 
Table 1

Star Bioscientists, Their Ties to Firms and Migration Rates

Top-10 Countries, 1973-1989

\begin{tabular}{|c|c|c|c|c|}
\hline \multirow[t]{2}{*}{ Countries } & \multirow{2}{*}{$\begin{array}{c}\text { Share of } \\
\text { stars }^{\mathrm{a}}\end{array}$} & \multirow{2}{*}{$\begin{array}{l}\text { Fraction } \\
\text { tied to firms }\end{array}$} & \multicolumn{2}{|c|}{ Migration Rate } \\
\hline & & & Gross $^{c}$ & $\mathrm{Net}^{\mathrm{d}}$ \\
\hline United States & 50.2 & 33.3 & 22.2 & 2.9 \\
\hline Japan & 12.6 & 42.3 & 40.4 & 9.6 \\
\hline United Kingdom & 7.5 & 9.7 & 58.1 & -32.3 \\
\hline France & 6.1 & 0.0 & 20.0 & 4.0 \\
\hline Germany & 5.8 & 0.0 & 50.0 & 8.3 \\
\hline Switzerland & 3.6 & 20.0 & 93.3 & -40.0 \\
\hline Australia & 3.4 & 7.1 & 35.7 & 7.1 \\
\hline Canada & 2.4 & 0.0 & 50.0 & -30.0 \\
\hline Belgium & 1.7 & 14.2 & 42.9 & 14.3 \\
\hline Netherlands & 1.2 & 20.0 & 80.0 & 0.0 \\
\hline Total for top 10 & 94.7 & 14.9 & 35.4 & -0.8 \\
\hline
\end{tabular}

Source: Adapted from Zucker and Darby (1999b), Table 1.

Notes: a. Total stars ever publishing a genetic-sequence discovery article 1973-1989 in this country as a percentage of total stars ever such an article 1973-1989 in any country. This involves some double-counting of multiple-country stars. Countries in the omitted rest of world with any stars are Denmark, Finland, Israel, Italy, Sweden and the USSR.

b. Percentage of stars ever publishing a genetic-sequence discovery article 1973-1989 in the country that ever published such an article in which the star or a coauthor was affiliated with a firm in the country.

c. Gross migration rate $=100 \times$ (immigration + emigration of stars) $/($ number of stars ever publishing in the country)

d. Net migration rate $=100 \times$ (immigration - emigration of stars)/(number of stars ever publishing in the country) 
Table 2

\section{Agglomeration or Diffusion? Correlation Coefficients for the Levels and Growth Rates of Articles, Firm Entry and Star Scientists \& Engineers}

\begin{tabular}{|c|c|c|c|c|c|c|}
\hline \multirow{2}{*}{\multicolumn{7}{|c|}{ Semiconductors Other Sciences Other Enginee }} \\
\hline & & & & & & \\
\hline University Articles ${ }^{\mathrm{b}}$ & $-0.07^{\star *}$ & $-0.08^{\star \star}$ & $-0.09^{* *}$ & $-0.08^{\star *}$ & $-0.04^{\wedge}$ & $-0.04^{\wedge}$ \\
\hline High Impact Articles ${ }^{b}$ & -0.02 & -0.04 & -0.03 & -0.03 & -0.03 & -0.04 \\
\hline Firm Entry & $0.09^{\star \star \star}$ & $0.16^{\star \star \star}$ & $0.22^{\star \star \star}$ & $0.20^{\star \star \star}$ & $0.17^{\star \star \star}$ & $0.04 *$ \\
\hline Star Scientists \& Engineers & $0.04^{\wedge}$ & $0.08^{\star \star}$ & $0.19^{\star \star \star}$ & $0.07^{\star \star}$ & $0.11^{\star \star \star}$ & $0.19^{\star \star \star}$ \\
\hline Star Scientist Entry & $0.29^{\star \star \star}$ & $0.53^{\star \star *}$ & $0.85^{\star \star \star}$ & $0.60^{\star \star *}$ & $0.73^{\star \star \star}$ & $0.73^{\star \star *}$ \\
\hline \multicolumn{7}{|l|}{ Top-25 S\&T Countries } \\
\hline University Articles ${ }^{\mathrm{b}}$ & $-0.16^{\star \star \star}$ & $-0.18^{\star \star \star}$ & $-0.18^{\star \star \star}$ & $-0.21^{\star \star \star}$ & $-0.08^{*}$ & $-0.16^{\star \star \star}$ \\
\hline High Impact Articles ${ }^{b}$ & $-0.08^{\wedge}$ & -0.06 & -0.08 & -0.05 & -0.05 & -0.05 \\
\hline Firm Entry & -0.04 & -0.01 & 0.00 & -0.02 & -0.02 & -0.04 \\
\hline Star Scientists \& Engineers & -0.05 & 0.04 & -0.01 & 0.00 & 0.02 & 0.01 \\
\hline Star Scientist Entry & 0.01 & $0.12^{*}$ & $0.53^{\star \star \star}$ & $0.13^{*}$ & $0.18^{\star \star}$ & $0.28^{\star \star \star}$ \\
\hline \multicolumn{7}{|l|}{ Top-24 Non-US S\&T Countries } \\
\hline University Articles $^{\mathrm{b}}$ & 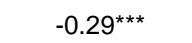 & 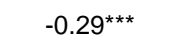 & $-0.23^{\star \star \star}$ & $-0.27^{\star \star \star}$ & $-0.15^{\star \star \star}$ & $-0.26^{\star \star \star}$ \\
\hline High Impact Articles ${ }^{b}$ & $-0.15^{\star \star \star}$ & -0.01 & $-0.13^{*}$ & $-0.09^{*}$ & $-0.11^{*}$ & $-0.09^{\wedge}$ \\
\hline Firm Entry & -0.03 & $0.10^{*}$ & $0.10^{\wedge}$ & 0.05 & 0.06 & -0.05 \\
\hline Star Scientists \& Engineers & -0.06 & 0.04 & $0.20^{\star \star \star}$ & $0.08^{\wedge}$ & 0.08 & $0.17^{\star \star}$ \\
\hline Star Scientist Entry & $0.19^{\star \star \star}$ & $0.73^{\star \star \star}$ & $0.93^{\star \star *}$ & $0.64^{\star \star \star}$ & $0.73^{\star \star \star}$ & $0.83^{\star \star \star}$ \\
\hline \multicolumn{7}{|l|}{ Non - OECD Countries: } \\
\hline University Articles ${ }^{\mathrm{b}}$ & $-0.42^{\star \star \star}$ & $-0.18^{*}$ & $-0.16^{\wedge}$ & $-0.32^{\star \star \star}$ & $-0.19^{*}$ & $-0.39 * \star \star$ \\
\hline High Impact Articles ${ }^{b}$ & -0.10 & $0.22^{\star *}$ & -0.08 & -0.12 & -0.11 & -0.12 \\
\hline Firm Entry & 0.13 & $0.28^{\star \star}$ & $0.45^{\star \star \star}$ & $0.29 \star \star$ & $0.42^{\star \star \star}$ & 0.03 \\
\hline Star Scientists \& Engineers & 0.00 & 0.05 & $0.67^{\star \star \star}$ & 0.31 *** & $0.75^{\star \star \star}$ & $0.42^{\star \star \star}$ \\
\hline Star Scientist Entry & $0.65^{\star \star \star}$ & $0.84^{\star \star *}$ & $0.90^{\star \star *}$ & $0.83^{\star \star \star}$ & $0.96^{\star \star \star}$ & $0.95^{\star \star *}$ \\
\hline \multicolumn{7}{|l|}{ OECD Countries (Including US) } \\
\hline University Articles ${ }^{\mathrm{b}}$ & $-0.16^{\star \star \star}$ & $-0.20 * \star \star$ & $-0.19 \star \star \star$ & $-0.21^{\star \star \star}$ & $-0.17^{\star \star \star}$ & $-0.16^{\star \star \star}$ \\
\hline High Impact Articles ${ }^{b}$ & $-0.08^{\wedge}$ & -0.07 & -0.09 & $-0.08^{\wedge}$ & -0.06 & -0.05 \\
\hline Firm Entry & -0.05 & -0.01 & 0.00 & -0.02 & -0.03 & -0.04 \\
\hline Star Scientists \& Engineers & -0.02 & 0.06 & -0.02 & 0.00 & -0.01 & 0.00 \\
\hline Star Scientist Entry & 0.00 & $0.13^{*}$ & $0.52^{\star \star \star}$ & $0.13^{\star}$ & $0.17^{*}$ & $0.25^{\star \star}$ \\
\hline \multicolumn{7}{|l|}{ OECD Countries (Excluding US) } \\
\hline University Articles ${ }^{\mathrm{b}}$ & $-0.3^{\star \star \star}$ & $-0.32^{\star \star \star}$ & $-0.24^{\star \star \star}$ & 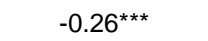 & $-0.29 \star \star \star$ & $-0.24^{\star \star \star}$ \\
\hline High Impact Articles ${ }^{b}$ & $-0.17^{\star \star \star}$ & -0.03 & $-0.15^{\star}$ & $-0.14^{\star \star}$ & $-0.12^{*}$ & $-0.09^{\wedge}$ \\
\hline Firm Entry & -0.03 & 0.08 & 0.09 & 0.07 & 0.04 & -0.05 \\
\hline Star Scientists \& Engineers & -0.02 & 0.06 & $0.19 * *$ & 0.07 & 0.02 & $0.15^{\star}$ \\
\hline Star Scientist Entry & $0.19^{\star \star \star}$ & $0.72^{\star \star \star}$ & $0.94^{\star \star \star}$ & $0.63^{\star \star \star}$ & $0.72^{\star \star \star}$ & $0.81^{\star \star \star}$ \\
\hline
\end{tabular}

Notes: Significance levels: ${ }^{\wedge} 0.10,{ }^{*} 0.05,{ }^{* \star} 0.01,{ }^{* \star *} 0.001$

a. The science and engineering areas are Biology/Chemistry/Medicine; Computing \& Information Technology; Semiconductors, Integrated Circuits \& Superconductors; Nanoscale Science \& Technology; Other Sciences; and Other Engineering. Nanoscale Science \& Technology articles and patents as defined for NanoBank.org are removed from the other five areas into which they would otherwise be classified.

b. University and high impact articles are measured as knowledge stocks computed as perpetual inventories with the input series the current year's publication of all university or high impact articles, respectively, and the depreciation rate set at 20 percent per year. These variables were among those used in the analysis of firm entry and accordingly articles with authors affiliated with firms were excluded in counting the input series. 
Table 3

Star Scientists' Professional Debuts and Migration Rates Top-25 Science and Technology Countries, 1981-2004

\begin{tabular}{|c|c|c|c|}
\hline \multirow{2}{*}{$\begin{array}{l}\text { Professional } \\
\text { Debuts }^{b}\end{array}$} & d Migration & Inward Migration & \multirow{2}{*}{$\begin{array}{l}\text { Net Inward } \\
\text { Migration }^{\mathrm{e}}\end{array}$} \\
\hline & Round & & \\
\hline
\end{tabular}

\begin{tabular}{|c|c|c|c|c|c|c|c|c|}
\hline \multicolumn{9}{|l|}{ OECD Member Countries } \\
\hline \\
\hline Austria & 14 & 6 & 1 & 2 & 20 & -4 & 10 & 36 \\
\hline Belgium & 37 & 7 & 1 & 2 & 15 & -5 & 32 & 54 \\
\hline Denmark & 29 & 5 & 3 & 5 & 15 & 0 & 29 & 49 \\
\hline Finland & 14 & 2 & 1 & 0 & 7 & -2 & 12 & 20 \\
\hline France & 135 & 20 & 19 & 22 & 114 & 2 & 137 & 265 \\
\hline Germany & 222 & 35 & 17 & 24 & 123 & -11 & 211 & 362 \\
\hline Italy & 60 & 14 & 11 & 16 & 47 & 2 & 62 & 120 \\
\hline Netherlands & 78 & 10 & 4 & 8 & 30 & -2 & 76 & 115 \\
\hline Norway & 12 & 2 & 1 & 3 & 13 & 1 & 13 & 27 \\
\hline Poland & 6 & 4 & 3 & 1 & 15 & -3 & 3 & 22 \\
\hline Spain & 13 & 1 & 1 & 8 & 29 & 7 & 20 & 49 \\
\hline Sweden & 70 & 12 & 7 & 5 & 40 & -7 & 63 & 112 \\
\hline Switzerland & 80 & 17 & 7 & 27 & 45 & 10 & 90 & 148 \\
\hline United Kingdom & 424 & 70 & 31 & 43 & 122 & -27 & 397 & 581 \\
\hline Europe $^{a}$ & 1194 & 205 & 107 & 166 & 635 & -39 & 1155 & 1960 \\
\hline \multicolumn{9}{|l|}{ APEC Member Countries } \\
\hline \multicolumn{9}{|l|}{ Non-U.S. APEC Countries } \\
\hline Australia & 97 & 15 & 10 & 25 & 49 & 10 & 107 & 170 \\
\hline Canada & 201 & 51 & 13 & 28 & 72 & -23 & 178 & 300 \\
\hline Japan & 176 & 5 & 15 & 18 & 76 & 13 & 189 & 266 \\
\hline South Korea & 1 & 0 & 0 & 4 & 7 & 4 & 5 & 12 \\
\hline Non-U.S. APEC ${ }^{a}$ & 475 & 71 & 38 & 75 & 204 & 4 & 479 & 748 \\
\hline United States & 3354 & 142 & 276 & 119 & 216 & -23 & 3331 & 3670 \\
\hline APEC Countries ${ }^{a}$ & 3829 & 213 & 314 & 194 & 420 & -19 & 3810 & 4418 \\
\hline OECD Member Countries ${ }^{a}$ & 5023 & 418 & 421 & 360 & 1055 & -58 & 4965 & 6378 \\
\hline \multicolumn{9}{|l|}{ OECD Nonmember Countries } \\
\hline Brazil & 1 & 1 & 0 & 3 & 15 & 2 & 3 & 19 \\
\hline China & 4 & 1 & 0 & 11 & 26 & 10 & 14 & 39 \\
\hline India & 10 & 3 & 1 & 3 & 14 & 0 & 10 & 27 \\
\hline Israel & 57 & 13 & 5 & 4 & 28 & -9 & 48 & 86 \\
\hline Russia/USSR & 7 & 4 & 0 & 4 & 27 & 0 & 7 & 36 \\
\hline Taiwan & 3 & 1 & 0 & 5 & 6 & 4 & 7 & 14 \\
\hline OECD Nonmember Countries ${ }^{a}$ & 82 & 23 & 6 & 30 & 116 & 7 & 89 & 221 \\
\hline Top-25 S\&T Countries ${ }^{a}$ & 5105 & 441 & 427 & 390 & 1171 & -51 & 5054 & 6599 \\
\hline Top-24 Non-U.S. S\&T Countries ${ }^{a}$ & 1751 & 299 & 151 & 271 & 955 & -28 & 1723 & 2929 \\
\hline
\end{tabular}

Source: Zucker and Darby (2007c)

Notes: a. Totals of individual country values have not been adjusted for doublecounting due to within-region migration.

b. Each person who publishes or patents giving an address in the country the first year that person publishes or patents anywhere is counted as making a professional debut in the country. It is possible for one star to make a professional debut in more than one country and in a country other than the country of his or her birth or citizenship.

c. One-way immigration refers to the person stopping publishing or patenting in a country where they had been doing so and starting doing that in another country with no subsequent return to the first country. "Visits" of 2 years or less do not count for inward or outward migration.

d. Round-trip immigration refers to the person stopping publishing or patenting in a country where they had been doing so and starting doing that in another country and subsequently returning to the first country. "Visits" of 2 years or less do not count for inward or outward migration.

e. Net inward migration is one-way inward migration minus one-way outward migration. Round-trip inward and outward migration leave the stock of stars unchanged.

f. The net stock of stars is the number making professional debuts in the country plus one-way inward migration minus one-way outward migration, with no adjustment for death or retirement due to lack of information on when that occurs.

g. Unique persons is a count of the number of stars who have ever published or patented with an address in the country. 
Figure 1. Estimated Effects of Number of University Star-Firm Linked Articles on Success of Californian and Japanese Biotechnology-Using Firms

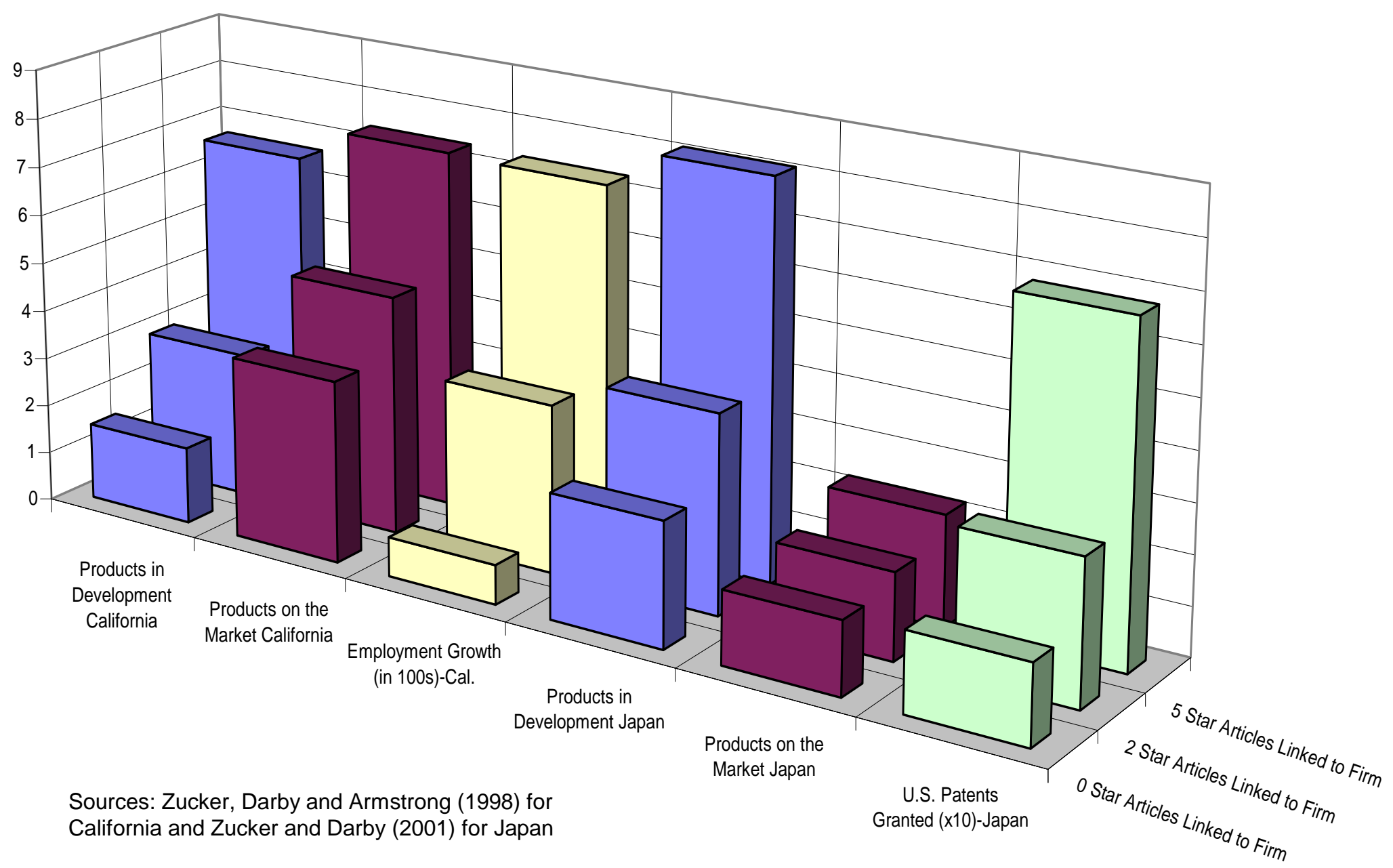


Figure 2. Success of US Biotech by Ties to Star Scientists, Links to Top-112-Research-University Faculty, and Venture-Capital Funding Levels

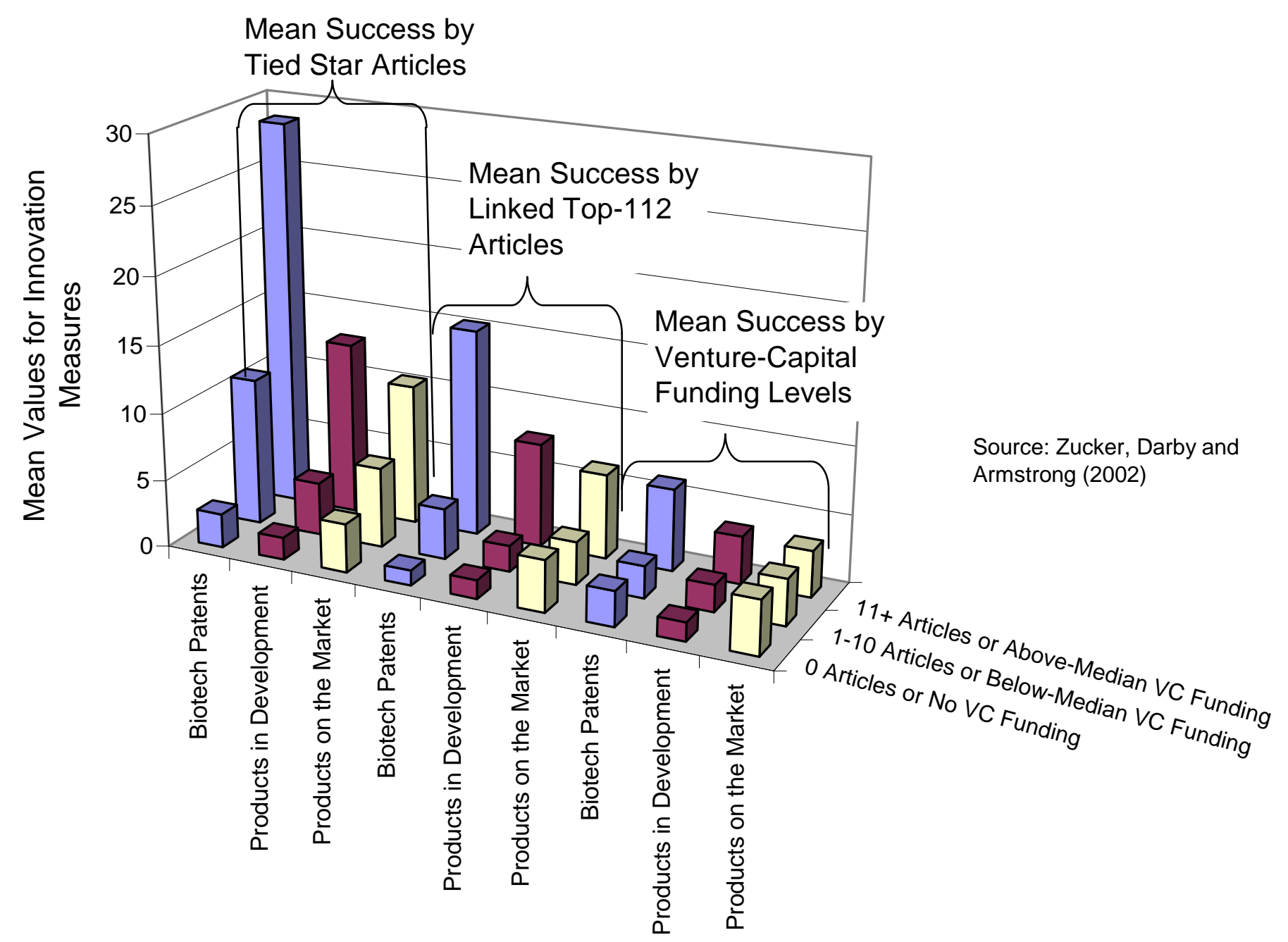


Figure 3. Biology/Chemistry/Medicine Star Scientists \& Firm Entry, US Regions, 1981-2004

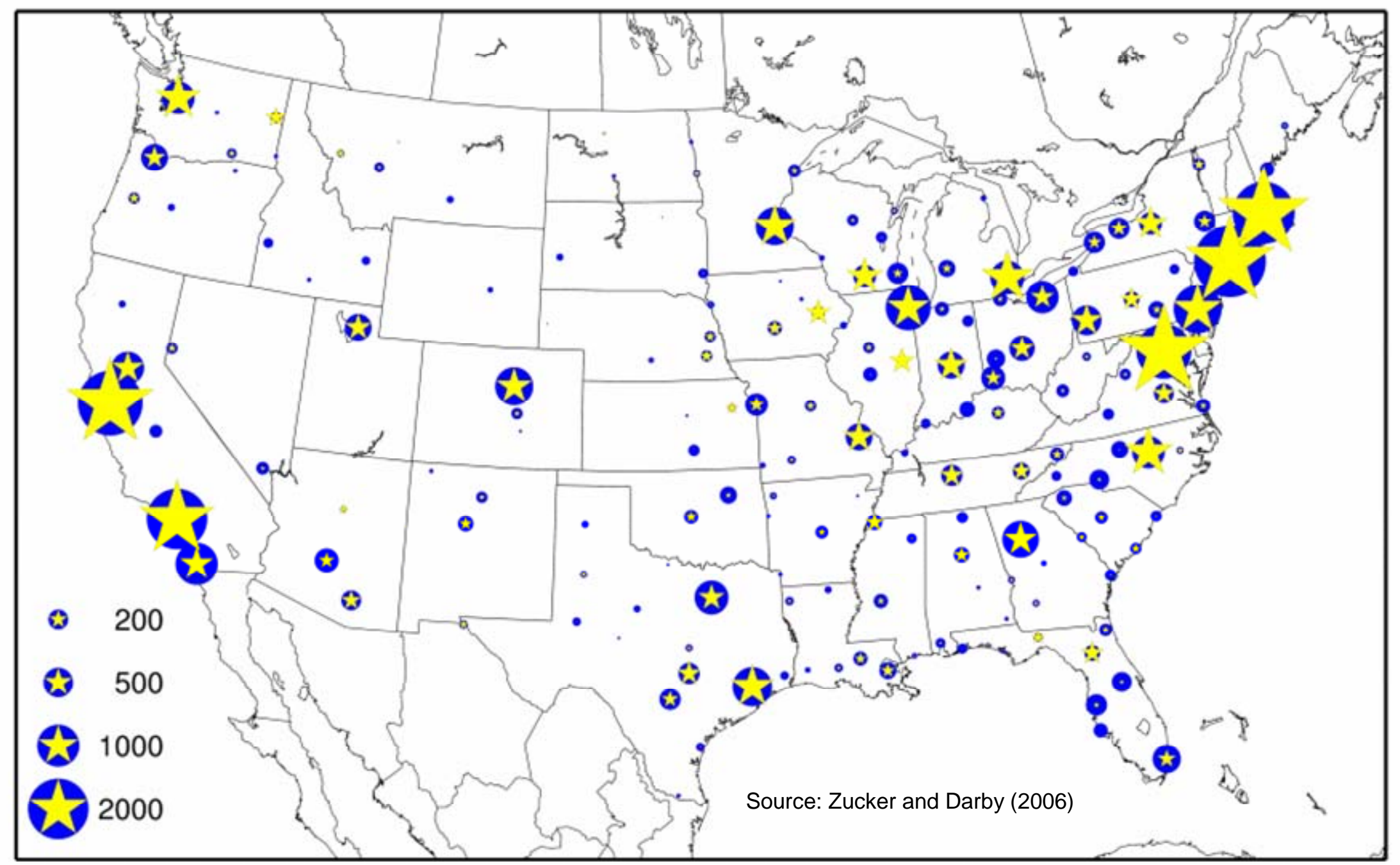


Figure 4. Nanoscale Science and Technology Star Scientists \& Firm Entry, US Regions, 1981-2004

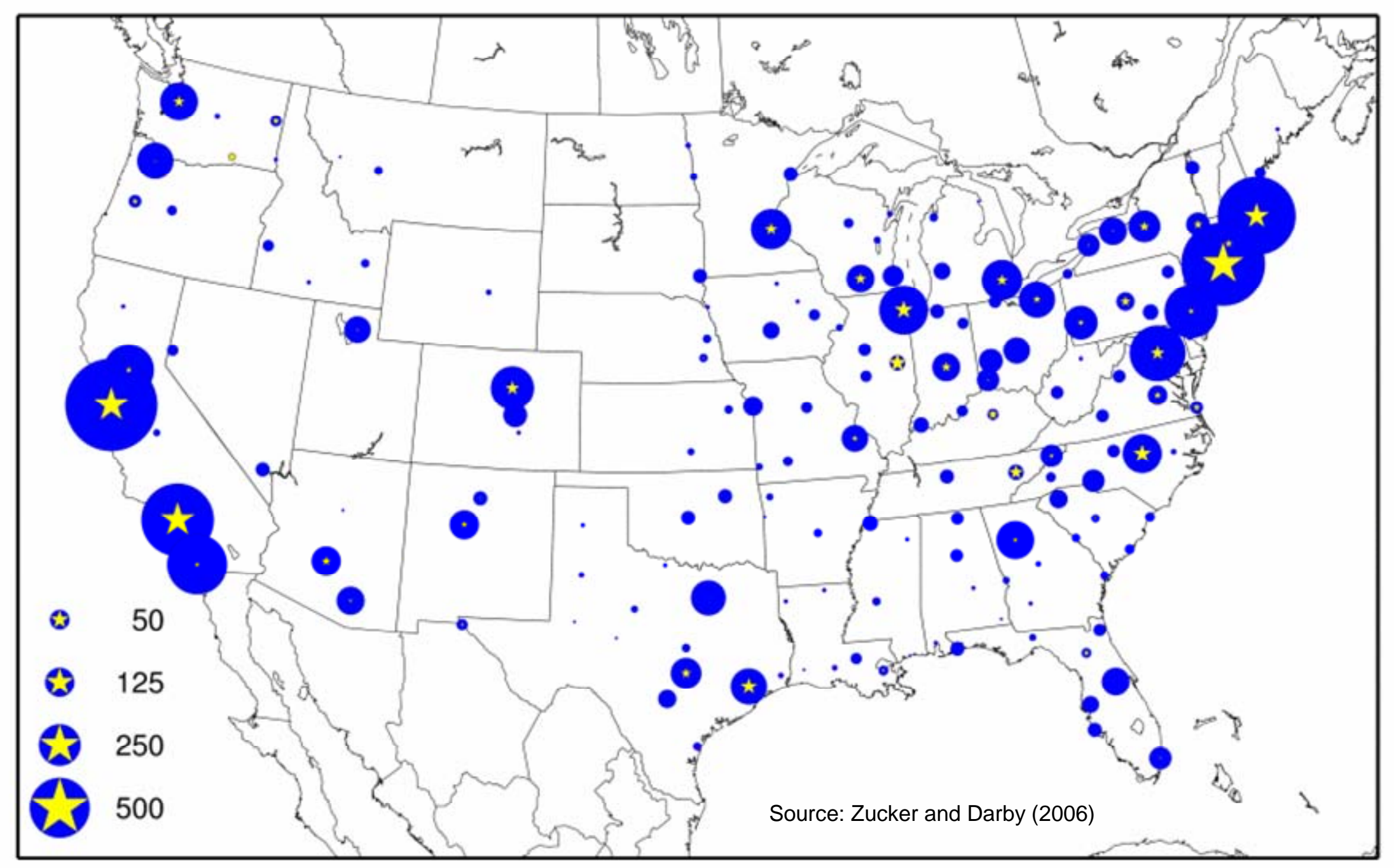


Figure 5. Biology/Chemistry/Medicine Star Scientists \& Firm Entry, 25 Countries, 1981-2004

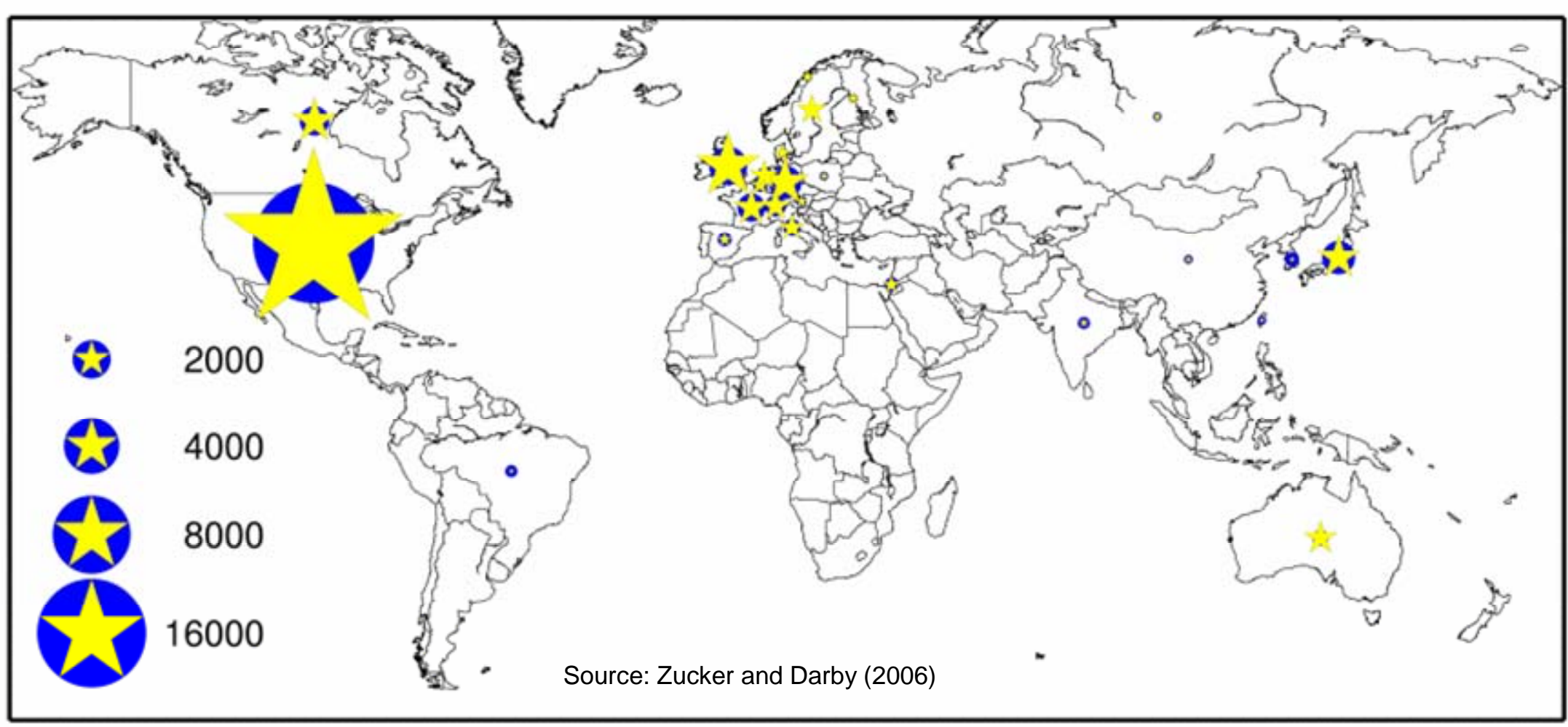


Figure 6. Nanoscale Science and Technology Star Scientists \& Firm Entry, 25 Countries, 1981-2004

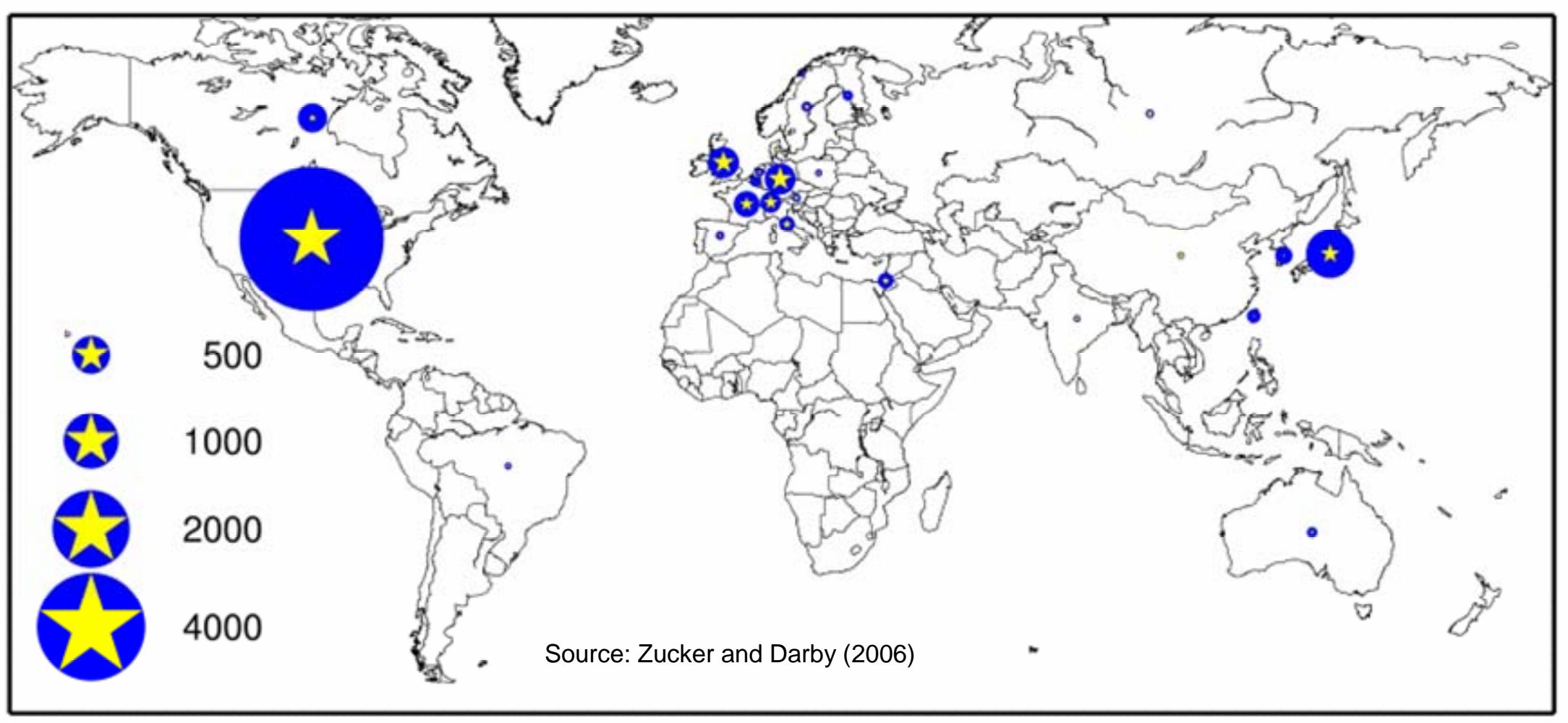


Figure 7. Star Scientists and Engineers Increase the Probability of Firm Entry into New Technologies Relative Probabilities with Different Numbers of Active Stars, All Other Variables = Mean Values

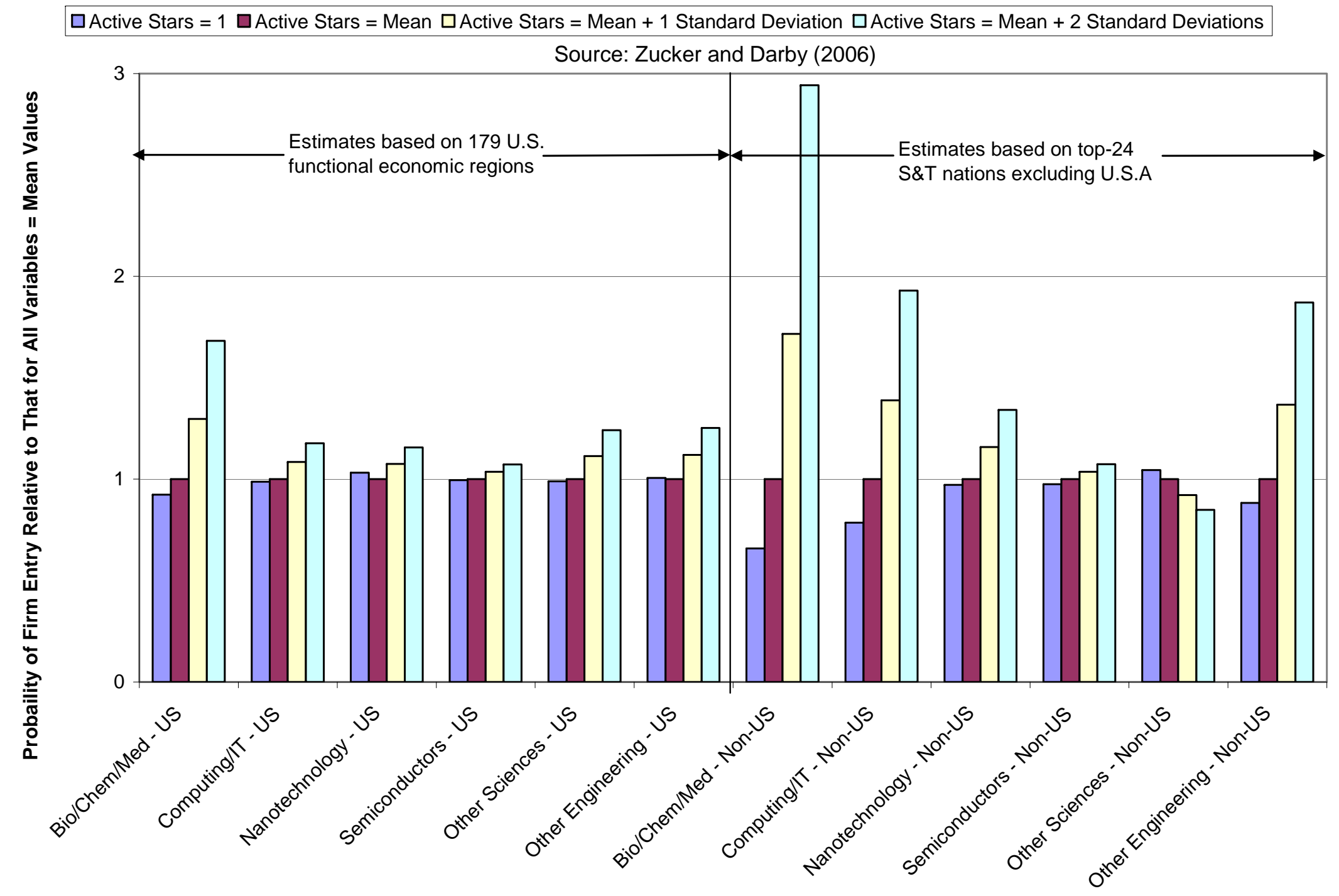


Figure 8. Star Scientists and Engineers Increase the Probability of Firm Entry into New Technologies Stars Defined as First 1,838 (First 34\%) in ISI HighlyCited ${ }^{\text {SM }}$

Relative Probabilities with Different Numbers of Active Stars, All Other Variables = Mean Values

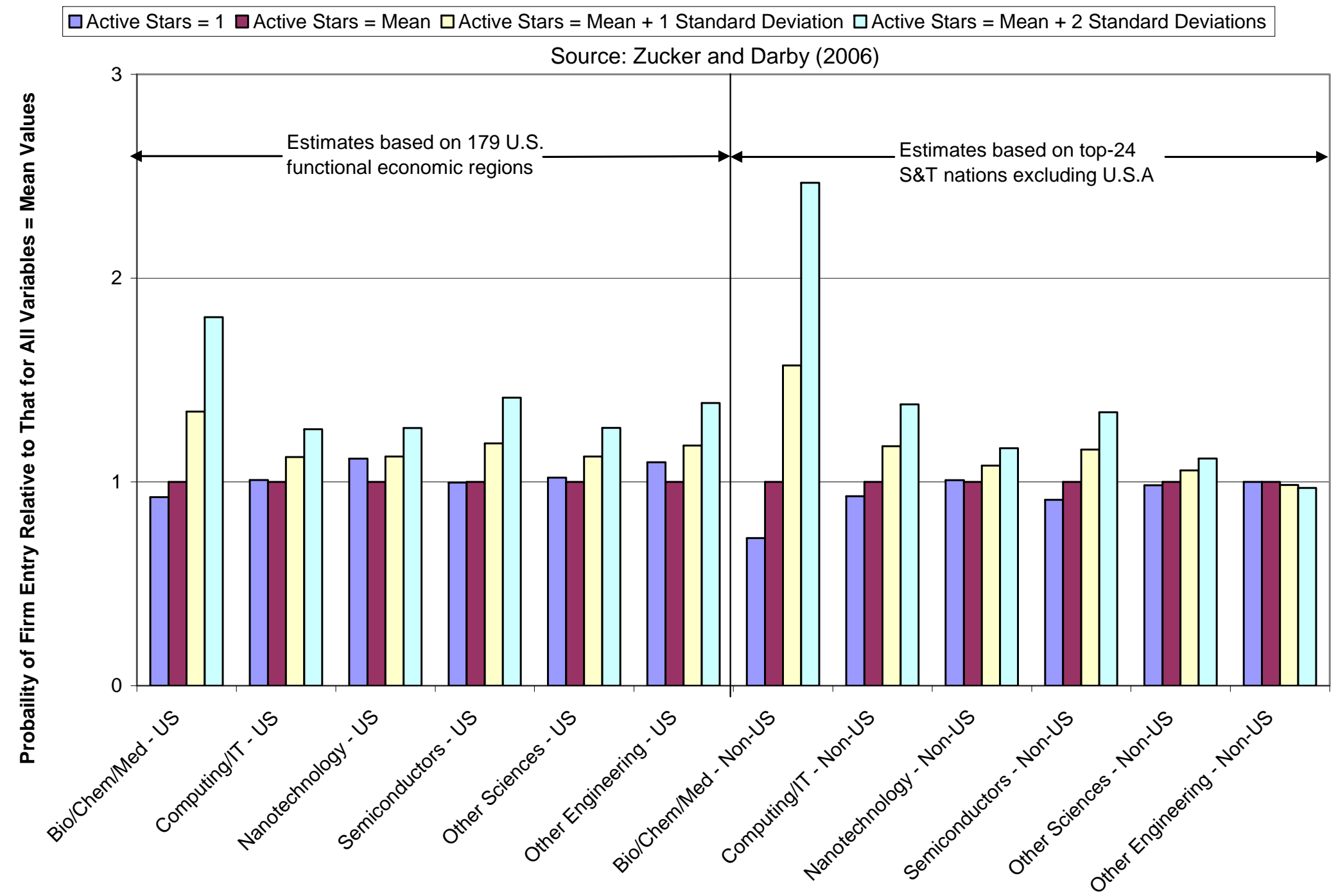

